\title{
13. The Janus face of social innovation in local welfare initiatives
}

\author{
Liisa Häikiö, Laurent Fraisse, Sofia Adam, \\ Outi Jolanki and Marcus Knutagård
}

\section{INTRODUCTION}

The aim of this chapter is to understand the relationship between local welfare initiatives and social innovation and how it varies across places. Since welfare policies must tackle increasing needs with scarcer resources, the topic of social innovation has become relevant. Social innovation expresses a shared hope for making things better in the future (Evers, 2015). It is a semantic magnet that attracts many different meanings and is charged with many positive connotations (Bergmark et al., 2011). As Martinelli (Chapter 1, in this volume) suggests, social innovation is an important dimension of the restructuring of social services and must be integrated into the analysis.

To explore the role of social innovations in the restructuring of social services, we analyse four local welfare initiatives in health and social services. By 'local welfare initiatives', we refer to collective practices that arise at the municipal or neighbourhood level for creating or sustaining the welfare of individuals, groups or communities through the provision of services. The local initiatives under study take place in four municipalities in different European countries and aim to renew social policy practices and services in neighbourhoods or for particular groups of people. Our focus is on the variations in the way social innovation is created and sustained in these local welfare systems, which we define as 'dynamic arrangements in which the specific local socioeconomic and cultural conditions give rise to different mixes of formal and informal actors, public or not, involved in the provision of welfare resources' (Andreotti et al., 2012, p. 1925). As a result, new local combinations of social activities emerge in the welfare diamond (Martinelli, Chapter 1, as well as Leibetseder et al., in this volume), i.e. among state and municipal services, social entrepreneurs, third sector organisations, and community and family networks (Evers and Ewert, 2015). 
By combining theoretical discussions on social innovation with empirical evidence from the cases, we argue that social innovation has an ambivalent character in local welfare initiatives. Different streams of theoretical and political discussion outline social innovation differently. The case studies highlight how local welfare initiatives combine different versions of social innovation, social practices and societal aims. The manner in which the notion of social innovation is mobilised is flexible and varies according to opportunities and context in a pragmatic way. Accordingly, we argue that socially innovative urban and local initiatives and experiments, and their consequences for local welfare systems, are decidedly Janus-faced (Swyngedouw, 2005).

In what follows, we first discuss the varieties of social innovation in the relevant literature and present the four case studies on local welfare initiatives. Subsequently, we analyse these local welfare initiatives from the perspectives of value orientation and institutionalisation. To conclude, we briefly summarise our findings and discuss the ambivalent nature of social innovation as part of local welfare solutions.

\section{SOCIAL INNOVATION AS A CONTINUUM BETWEEN TWO APPROACHES}

Thinking about social innovation has progressively emerged during the 2000s, first in the academic sphere (Moulaert et al., 2010) and then on the political agenda. The historical roots of social innovation have been related to the self-organised political and economic experimentations that emerged within the first worker's associations and movements, i.e. the utopian, mutual aid and cooperative experiences of the early period of industrialisation in the nineteenth century (Martinelli, 2010). However, social innovation as an explicit concept was first used to describe the wave of new practices and strategies that evolved in the late 1970s and early 1980s from new social and urban movements (Touraine, 1981; Chambon et al., 1982; Castells, 1983; Lévesque, 2007). Grassroots initiatives based on protest and activism were aimed at meeting unsatisfied local welfare needs and improving living conditions. These community initiatives providing new social services often presented themselves as emancipatory practices compared to existing bureaucratic and paternalistic social services, inspiring academic discussion on social innovation.

Compared to this first period, one of the major shifts in the last fifteen years has been the end of the monopoly held by the civil society and the academic world over social innovation discourse and actions. During the last decade, social innovation has also received political attention in 
the context of economic austerity. It has become a new EU-sponsored policy agenda for responding to the financial crisis. The idea has become subject to some forms of regulation and funding, not only at the EU level but also at national and local levels (Fraisse, 2013). At the EU level, one of the main objectives of the Europe 2020 strategy is to promote economically efficient social innovations that facilitate smart, sustainable and inclusive growth and address the needs of the most vulnerable groups in society (see Gómez-Barroso et al., in this volume). Socially innovative strategies aim to mobilise the entire society to meet welfare needs and to provide social services. However, the EU innovation agenda, supported by dedicated social programmes and research funding, coexists with strong recommendations for austerity measures and cuts in public spending in the Eurozone. Austerity policies have accelerated welfare retrenchment, especially in Southern European countries (León et al., 2015), and have weakened the ability to invest in social services. In this context, there is a risk that national and local governments can interpret social innovations as substitutes or default solutions under the pressure to cut social spending.

The multiple roots of social innovation reveal different types of thinking. With reference to the political and academic discussion on social innovation, two main perspectives can be identified: a more mainstream discourse and a more radical view. Despite the similarities of these two perspectives with the two 'schools' of social innovation - one technocratic, the other democratic - as recently characterised by Montgomery (2016), we do not consider the mainstream policy discourse and the radical view as being fully alternative paradigms but rather as reference points in the intellectual discussion on the varieties of social innovation. In other words, distinguishing between these two lines of thinking is a heuristic device for positioning the varied meanings that social innovation can take in the restructuring of local welfare and service systems. The zone between these two poles is populated by highly variegated academic conceptualisations, political discourses and social practices (for example, see Gallouj and Djellah, 2010; Nicholls et al., 2015).

In our simplified dichotomy, the EU policy agenda (BEPA, 2010; European Commission, 2013) can be placed within the mainstream discourse, which focuses on the development and implementation of 'new ideas (products, services and models) to meet socially recognised needs and create new social relationships or collaborations' (Mulgan, 2012, p. 22). Having a functionalist logic, this definition understands social innovations as local strategies to preserve social cohesion in times of crisis and tends to stress cost-efficient solutions from the social entrepreneurship perspective as well as social experimentations by local authorities. In our opinion, it reinforces the neo-liberal agenda by introducing business methods and 
resources in the management of social services, extending the rules of competition to the delivery of social services and prioritising cost-efficiency within restricted public budgets. Social innovations are viewed as responses to the failure of the state to provide public goods and to the failure of the civil society to provide effective goods and services to their beneficiaries (Nicholls et al., 2015).

The more radical view refers to Moulaert's definition of social innovation (Moulaert et al., 2005; also see Klein et al., 2014) as grassroots initiatives that develop to satisfy unmet basic human needs, to empower excluded social groups and communities to access social and citizenship rights, to change power relations and to transform governance practices. It includes the potential for resistance to welfare dismantlement and the neo-liberal agenda. Social innovations that emerge from such grassroots movements implementing social change strategies are a potential source for counterhegemonic projects (Moulaert et al., 2007). This notion of social innovation provides an alternative perspective on society and the reform of services.

In practice, the abovementioned differences are not always that sharp. The use of the social innovation concept is often flexible and varies according to opportunities and context in a pragmatic manner. Both the mainstream policy discourse and the radical view on social innovation integrate a normative dimension and, hence, a value orientation. From both perspectives, social innovation is a positive social phenomenon, either for incremental improvement or transformative social change, 'progressing toward something better' (Brandsen et al., 2016, p. 6). They both value bottom-up initiatives as the drivers of social innovation (Manzini, 2014; Rønning and Knutagård, 2015), thereby emphasising the importance of the local scale as the appropriate locus for effective governance. Social innovation emerges when people or 'the final recipients' are directly involved in the local decision-making process and the co-production of social services (Moulaert et al., 2007).

However, the two views on social innovation differ in their understandings of the social dimension. For the mainstream policy discourse, the social is a resource. Consumer involvement or mutual-help practices among ordinary people become a key instrument for cost-effective strategies in the restructuring of social services. Citizens participate in order to solve common problems, deliver care, form communities of mutual help, innovate and, most importantly, save public money (Häikiö, 2010; Manzini, 2014). Although their outcomes have great importance for the individuals and their well-being, these initiatives do not challenge or change social relations since social resources are not mobilised beyond the everyday life of the actors involved. The mainstream approach prioritises social stability 
and the maintenance of the social order. Therefore, the changes expected from the institutional support for innovative welfare services are limited to strengthening social cohesion.

For the radical view on social innovation, the social has a relational dimension, including power relations, and social innovations emerge from empowering processes that restructure social relations. Changes in social relations are regarded as a precondition for addressing major social problems. In addition to improving the well-being of the specific context in which they are developed, the new processes of service provision challenge the existing power relations, empower people and promote equality. This occurs through the engagement of civil society associations and/or social movements in socially innovative practices (Gerometta et al., 2005). Through their potential to identify and address the unmet needs of local people, socially innovative practices are related to collective actions and social transformations from the bottom up (Moulaert et al., 2013). Such socially innovative services have the potential to mobilise social resources and empower social groups that are excluded from or dissatisfied with certain social services. From this perspective, social innovation relates to the emancipatory agenda of social policies, as analysed by Mätzke et al. (in this volume).

To summarise, the mainstream and radical policy discourses on social innovation diverge in regard to:

- their intention and capability to challenge disempowering social relations;

- the societal reach of the changes involved;

- their standing with regard to the neo-liberal restructuring of social policies and services.

As stressed above, the aforementioned distinctions do not feature clearcut models but highlight how social innovation in local welfare initiatives has a Janus face (see Swyngedouw, 2005). The varied forms of social innovation in the restructuring of local welfare systems relate to multifaceted value orientations and institutionalisation strategies.

In our interpretation, value orientation relates to the understanding of social innovation itself and to people's impetus to participate in creating and establishing social innovation. In the radical approach, social innovation has 'a value orientation in conflict with mainstream hegemonic values', encompassing the quest for progressive social change including social justice, environmental protection, gender equality, empowerment and so on (Vicari Haddock and Tornaghi, 2013, p. 265). In mainstream policy discourse, social innovation has a value orientation that is in line 
with the retrenchment, re-commodification and re-familisation of social services. The controversial aspects of these definitions are a source of the ambivalent interpretations of social innovation and also shape local welfare initiatives for providing and reforming social services. Value orientation is thus vocal for analysing not only the normative dimensions of social innovation but also the interplay between different actors and organisational forms of new initiatives, 'raising locally hopes and expectations within the sociopolitical and socioeconomic context of their emergence' (Brandsen et al., 2016, p. 6).

Institutionalisation, in turn, refers to the capability of local initiatives to have an influence on the public discourse and their potential to be sustained and transformed from experiments at the local scale into new socialpolitical practices in the delivery of social services. The ability of local welfare initiatives to be integrated within governance arrangements and to consolidate institutional change means going beyond the pragmatic and local benefits achieved through the diffusion of a new social practice. It requires taking into account the strategic links between 'micro' social innovation and 'macro' institutional and social changes (Jessop et al., 2013). This multiscalar dimension is crucial for assessing the sustainability and institutionalisation of innovative practices. The long-term sustainability of socially innovative services depends on their ability to influence and be integrated into the regulatory and financial frameworks of social policies.

\section{THE CASE STUDIES ON LOCAL WELFARE INITIATIVES}

The four case studies selected for our analysis of social innovation include local welfare initiatives in health and social services from different welfare models and regulatory systems. These different sociopolitical contexts also embed different sociocultural contexts with specific local norms and social relations. These contextual characteristics create distinct circumstances and environments for social innovation (Grimm et al., 2013).

Three of the four cases were studied in the course of the COST Action IS1102 SO.S. COHESION - Social services, welfare states and places - two from Nordic countries (Helsinki, Finland and Helsingborg, Sweden) and one from Southern Europe (Thessaloniki, Greece) (see CAP Knutagård, 2014; CAP Adam and Papatheodorou, 2014; CAP Jolanki, 2014). Another was added from Continental Europe (Lille Metropole, France) (Fraisse, 2016). These countries have different welfare frameworks. In Finland and Sweden, public social services play an important role in welfare provisions for all citizens. Public participation has been integrated into the services 
through civil society activities and the legislative rights of service users (together with municipal democracy, councils and so on). France and Greece are characterised by greater differences among regions and social groups. Moreover, in France, the long tradition of the welfare state and the provision of social services have been affected by a lengthy deindustrialisation process and structural long-term unemployment. In Greece, the financial crisis and the European austerity agenda have involved dramatic cuts in social spending, with relevant impacts on society.

\section{The Cases from the Nordic Countries}

Housing First in Helsingborg (Sweden) is based on a global idea developed in New York in 1992 by the Pathways to Housing non-profit organisation (Tsemberis, 2010) that diffused to other countries and was also adopted in a context representing the Nordic model. In 2009, the Director of Social Services in Helsingborg embarked on the implementation of this model in an attempt to combine the independent model of the service user with the tradition of the Nordic welfare state. The principles of Housing First significantly differ from the traditional 'treatment first model', with the latter emphasising abstinence from alcohol or drugs as a precondition for access to housing (Knutagård and Kristiansen, 2013; CAP Knutagård, 2014). By contrast, Housing First considers housing to be a prerequisite for the individual to accomplish other changes in life, makes a clear distinction between housing and treatment, and prioritises the active participation of homeless people in the design and provision of services. Recovery and harm reduction are also key ingredients in this approach.

The other case from Nordic countries, a senior co-housing unit in Helsinki (Finland), is an endeavour by a group of older women to create co-housing for their old age. The social and cultural context in which the process of building senior co-housing occurred is connected to the development and changes in Finnish services for older people. For a long period of time, public discussion and government reports on older people's housing and care have revolved around the problems in the availability and quality of both home-based care services and residential services. The discussion created an image of helpless people abandoned in their homes or mistreated in institutional care structures. The co-housing unit arose as an antidote to the prevailing image and practices of housing services for older people (Jolanki and Vilkko, 2015). The co-housing initiative represents an attempt to create housing and care alternatives by older people for older people (CAP Jolanki, 2014). In 2006, the residents moved into this multistorey house with privately owned apartments and a common space, but the building process had begun much earlier, in 2000. A civil association 
was created to co-operate and negotiate with banks, builders and city professionals. The senior co-housing unit of Helsinki is the first of its kind in Finland. The core principles of the co-housing initiative revolve around the self-management and collective decision-making of the residents. It functions in a non-hierarchical manner, without paid care workers. Therefore, it differs from the tradition and practices of ordinary senior housing and services organised by other formal actors, such as NGOs, municipalities, or the private for-profit sector, which offer limited channels of influence to residents. The overall intention is not only to create an active social life, mutual help and meaningful activities for old age but also to have an influence on the housing and services that are offered for older people.

\section{The Case from Continental Europe}

The urban co-planning initiative in Lille Metropole (more specifically in the Roubaix-Tourcoing-Wattrelot district; Ilot Stephenson) can be considered a pilot project to test an alternative approach to urban renewal. The architect Patrick Bouchain and his colleagues launched the Construisons ensemble, le grand ensemble (Working together to build the neighbourhood) concept, which was applied between 2009 and 2012. The socially innovative local initiative in urban co-planning was initiated as a protest by inhabitants against the demolition of their housing and living area in a remote district of a larger urban renewal project, in the context of a deindustrialised area of a country within a Continental welfare state.

The conflict was transformed into a co-operative resource for renewal, and the protest evolved into a housing co-production action involving architects, local authorities and the residents' organisation. The architects located part of their office in the area, and the daily presence changed the relationships with the inhabitants and other stakeholders as well as the architects' perception of their initial architectural scheme by setting it against the backdrop of the habits and needs of everyday life. The project office was transformed into a public space where participation and communication between residents and architects occurred. The co-production addressed the reduced costs of housing, living possibilities for vulnerable groups, employment and education as well as new architectural models, encouraging the residents' participation in the self-rehabilitation of their neighbourhood.

\section{The Case from Southern Europe}

The Solidarity Clinic in Thessaloniki stems from the initiative of a group of health professionals and activists in solidarity with the hunger strike 
of 50 migrants in Thessaloniki in 2011. Universal public health care was never fully implemented in Greece, despite the introduction of a National Health System in 1983, due to a number of flaws in the policy design and implementation. After the introduction of the austerity measures following the 2008 financial crisis, the Greek government opted for dramatic cuts in public health expenditure (Kentikelenis et al., 2014). The budget for public hospitals was reduced by 40 per cent as admissions simultaneously increased by 30 per cent (Ifanti et al., 2013). The Solidarity Clinic was a response to this situation, and particularly to the demand of the Ministry of Health to exclude undocumented migrants from public health care as a fiscal cost containment strategy.

The core operating principles make it different from traditional public health care provision and other social clinics initiated by other formal agents (NGOs, municipalities, the church). These principles include an anti-racist orientation, the provision of service to all persons in need, a non-hierarchical structure, self-management and collective decisionmaking, rigid criteria for accepting funding and donations (i.e. not from political parties, EU programmes, private for-profit companies), and exclusive dependence on voluntary and unpaid staff. This initiative inspired other similarly minded solidarity groups across the country, and they eventually formed a network to better channel their political demands. However, they are reluctant to collaborate with the state and to become institutionalised for fear of losing their autonomy and resistance strategy. The Solidarity Clinic in Thessaloniki displays innovative aspects that are mostly related to the operational model it follows (non-hierarchical management, non-screening of potential beneficiaries) and the political advocacy role that it plays through public events.

\section{The Analytical Perspectives on the Cases}

Next, we turn to the analysis of social innovation in the four local welfare initiatives in health and social services above. We build on the methodological approach proposed by Vicari Haddock and Tornaghi (2013) and mobilise the following parameters for our assessment: value orientation and institutionalisation.

As stressed above, the value orientation dimension of social innovation encompasses not only the normative dimensions for social change but also the relations between different actors and organisational forms of new initiatives. Social innovation stems from the interplay of a multiplicity of actors, ranging from civil society and everyday life actors to public services and local governments, which all hold diverse values. Moreover, the diversity of actors and social relations means differences in the resources 
and capabilities to which these actors have access. This relates to material conditions, but equally important is the articulation of identities and interests (Häikiö, 2007; Moulaert et al., 2007). Therefore, intertwined material and discursive circumstances shape the value orientations that define the meaning and practices of social innovation.

Institutionalisation refers to the capability of local initiatives to sustain broader changes by being replicated, reproduced over time, and embedded in formal institutions in two main ways: by triggering changes in the public discourse and broadening the spectrum of models and practices, and by being formalised beyond the local scale through linkages with state authorities (Vicari Haddock and Tornaghi, 2013). Therefore, the fulfilment of the socially innovative potential of local initiatives in social services is significantly articulated with scale. Local initiatives inherently refer to local social relations, resources and needs. Social innovation may be locally based, but its real potential unfolds when it bypasses the local and affects the broader society (see Manzini, 2014). In particular, social innovation in urban governance relations signifies the establishment of new inclusive social practices for participation (Gerometta et al., 2005). In addition, sustained changes may occur through the replication of local initiatives in new places and at other scales.

\section{THE JANUS FACE OF SOCIAL INNOVATION}

\section{Value Orientation: Mobilising Co-operation}

Value orientation is related to the contexts in which local welfare initiatives are created and established. The Housing First initiative in Helsingborg and senior co-housing in Helsinki represent local initiatives that engaged with the mainstream policy discourse on social innovation and, by doing so, challenged the established local welfare practices and social services by considering people as contributors and active participants. This, in turn, contributed to the diversification of welfare provision. Although these local welfare initiatives challenged the dominant sociocultural context of 'normal procedures', they improved welfare practices within the existing welfare systems and sociopolitical contexts. They aimed to improve welfare practices with new ideas on methods of providing services to meet the welfare needs of particular groups of citizens. In line with the EU approach to social innovation, they stress cost-efficient solutions for social services and social experiments for renewing local practices.

The two other cases, urban co-planning in Ilot Stephenson in Lille Metropole and the Solidarity Clinic in Thessaloniki, relate to the ideas rep- 
resented by the radical view on social innovation, which aim to empower excluded social groups and to transform power relations. Both of these local initiatives aim at resisting welfare dismantlement in the realms of housing and health care, respectively. In the case of the co-planning initiative in Ilot Stephenson, the context of deindustrialisation is a long-term regional process, and the innovative practice is a local reaction to a vast national and regional urban renewal programme. However, the promotion of the inhabitants' participation in the production or rehabilitation of social housing is an urban planning alternative that has not been considered a priority in the national demolition-reconstruction programme in France.

The emergence of the Solidarity Clinic is strongly related to the financial crisis and the European austerity agenda. The value orientation of solidarity and a horizontal decision-making process as a resistance strategy to neo-liberalism and racism correspond to the willingness to transform users into active participants in the social struggle for universal public health care.

Despite these contextual differences in value orientations, all four local welfare initiatives perform co-production practices that include horizontal co-operation among actors and vertical integration between local and national welfare institutions. All involve the participation of civil servants, professionals and people in a co-operative manner, with the aim of creating material and cultural resources for socially innovative activities. All show how the commitment of these diverse actors mobilises resources and capacities for local initiatives to establish and sustain socially innovative practices.

All of the initiatives start with a small group of actors. Social service professionals initiated the Housing First pilot project, seeking to make policies for homelessness more effective. A group of health professionals took action with the Solidarity Clinic as an answer to the lack of health care. The co-housing unit arose from the initiative of a group of citizens who joined together to prepare themselves for future housing and care needs. The urban co-planning initiative emerged from the activities of workingclass inhabitants who organised and protested against the demolition of their houses. However, these groups were also able to attract and mobilise other actors. For example, the Ilot Stephenson co-planning initiative started as a conflict between inhabitants and authorities but, after several years, opened a new space for co-operation among inhabitants, planning authorities and professionals. The demolition project was stopped, and the Lille Metropolis authorities decided to transfer the management of the urban renewal development to a semi-public company with an obligation to properly integrate sustainable development and participatory 
approaches in the planning process. The architect Patrick Bouchain and his team were invited to rethink the urban project with the inhabitants of the neighbourhood.

Another important aspect is the potential of a local initiative to build a contextually shared value orientation and cultural capacity for defining and articulating new identities and interests. Although all of the cases contribute to the cultural capabilities of citizens and professionals to engage with the socially innovative co-production of welfare, in the local initiative of Housing First, social innovation was precisely about creating a space for identity politics that increased the cultural capabilities of the homeless. This was not the key intention when the local initiative was taken, but the implementation of the pilot opened a space for the engagement of a group of tenants with a long history of homelessness. These tenants could not join established service user organisations if they were on medicationassisted treatment. Therefore, they formed their own peer-support organisation to share their experiences and to address their particular social needs for housing. The social services offered a place where the Housing First tenants could meet, and later on they took charge of the facilities themselves. The co-production of the different activities between the Housing First tenants and the social workers has led to an increased trusting relationship between the two parties (CAP Knutagård, 2014; Sanders and Stappers, 2008).

The trajectories of social innovations studied from the value orientation perspective differ depending on whether their practices include a contentious aspect in their relationship with local authorities and established institutions. A 'conflictual co-operation' dynamic is present in local initiatives that articulate a radical view on social innovation. Those that are in line with the mainstream policy discourses on social innovation generally aim to establish co-operation by negotiation and dialogue with authorities.

All of the cases, however, articulate social relations in a similar manner. They construct social relations that simultaneously address local problems and take action for a better future. Doing so creates a space for public participation and co-operation. For example, in the Lille Metropole area, the co-planning initiative articulated social relations so that the inhabitants' participation in the production of social housing and the rehabilitation of the area became a key principle for improving co-habitation in the city. In turn, the co-housing initiative in Helsinki emphasised the right of older people to be treated as individuals, ensuring their own choices with collective practices of co-operation, social interaction, mutual help and support. At a very practical level, the rationale for senior co-housing integrated individualistic and collective understandings of better ageing. To date, the 
socially innovative potential of the co-housing initiative has been more cultural than political in nature.

\section{Institutionalisation: Moving Across Scales}

The institutionalisation perspective can be assessed at different levels. First, social innovations travel from place to place. Our cases demonstrate how local welfare initiatives are not limited to the local. Since the first experiments in the United States at the turn of the 1990s, the Housing First initiative has progressively become a global policy concept that has been replicated in different places. In Sweden, the example from Helsingborg has made the model more attractive to other local authorities. The senior co-housing unit in Helsinki followed the example of the 'Färdknäppen' Swedish collective housing unit, founded in the 1970s. The co-housing unit has also received major attention in Finnish public discussion, giving birth to other initiatives. The Ilot Stephenson co-planning initiative in the Lille Metropole area was not developed in a vacuum but had its roots in the idea of participatory urban planning and developed into a showcase for these types of practices with local and regional publicity. The Solidarity Clinic in Thessaloniki relates to the anti-austerity solidarity movement in Greece. The practices developed there have influenced other clinics. It has offered technical expertise to other Solidarity Clinics across Greece.

Second, all local welfare initiatives are connected to more or less institutionalised networks, processes and resources from other scales. In all four cases, the co-production of services depends on the capability of the actors involved to build multi-stakeholder and multilevel coalitions. Professionally driven initiatives needed to open spaces for the participation of citizens. Citizen-driven initiatives needed to engage with professionals and civil servants in co-operative ways to transform their modes of working and to promote social innovation. For example, many of the residents in the senior co-housing initiative in Helsinki were people with higher education, such as former journalists and doctors, with good educational, financial and social resources, but they also required support and resources during the process from various institutional actors. City officials and funding agencies provided advice concerning rules and regulations as well as on how to organise the funding of the construction. Small grants were given by the city of Helsinki and the Ministry of Social Affairs and Health for the preparation of the project. Similarly, the success of the Solidarity Clinic must be attributed to the engagement of a large number of other health and non-health professionals, apart from the founding team. In terms of financial support, the Solidarity Clinic relied on trade unions and individual citizens from within Greece and abroad. 
Third, institutionalisation and up-scaling are a major challenge for local welfare initiatives and highlight the political character of social innovation. Shifts between governance scales from the local level to the national or international level illustrate the potential of socially innovative initiatives for societal change. All four cases show how the up-scaling of social innovation largely depends on the ability of local initiatives to become visible at other scales and to affect the public discourse on social policy.

The success of the Ilot Stephenson housing renewal has been possible because of the mediation of a well-known architect and his team at the national level, which accelerated local innovation processes and overcame resistance at the local level. The impact of the project went far beyond the local community. Many architecture professors and students, delegations of technicians from other cities and even international visitors have been visiting the building site and meeting the urban planning team. The architects have conceptualised and communicated the new urban approach to social housing construction and urban rehabilitation through publications, conferences and videos. One of the architects who worked in the Stephenson neighbourhood throughout the entire project even won a prize for young urban planners in 2012.

The senior co-housing in Helsinki has also received national attention through widespread media coverage, which has enabled public discussion and the dissemination of the idea and experience among citizens and institutional actors. Over the years, countless articles have been published in newspapers and magazines. The residents have taken an active role in spreading the idea through a book (Dahlström and Minkkinen, 2009), a website and various blogs. The place itself has been visited by a large number of visitors. Although the idea of senior co-housing has taken some time to take root and foster new initiatives, currently the National Development Programme for Housing for Older People 2013-2017 (Ikääntyneiden asumisen kehittämisohjelma 2013-2017) includes the goal of increasing alternative housing options for older people, particularly those that enhance community participation, reciprocity, mutual help and support, thus feeding into a sense of community. Recently, new funding has been reserved to study the possibilities of facilitating similar types of innovative solutions and implementing them in the future.

The Solidarity Clinic of Thessaloniki was one of the initiators of a broader network of autonomous Solidarity Clinics all over Greece, which collaborate both in practical aspects (for example, in the circulation of prescription drugs) and the organisation of public events (demonstrations for universal public health care). It has also managed to garner attention from international audiences through international field visits of activists and the participation of the Solidarity Clinic's members in campaigns abroad. 
However, despite this movement among implementation scales, the institutionalisation of local welfare initiatives and social innovations in urban or national governance seems to be rare. Local initiatives relying on the mainstream policy discourse on social innovation are not targeting governance arrangements or aiming at direct institutional change. They connect with upper scale institutions and actors for practical reasons. For these local initiatives, governance is a context for their activities, not a site of transformation, and their inherent aspects of identity politics that promote new cultural capacities do not transform into struggles for social change. For example, when the city of Helsinki did not seriously consider that the senior co-housing unit would be a stakeholder in organising health care services for a wider community, the residents pragmatically turned to private providers to organise those services. Despite all the public interest, no institutionalisation process has taken place in relation to senior co-housing in Finland or Helsinki. On the other hand, the ideas that underlie the co-housing model have been reinterpreted, and new examples of communal types of housing are being developed with the assistance of institutional actors. To date, they offer a complementary example to the mainstream welfare model and housing options. Similarly, the scaling-up of the Housing First pilot initiative - as with other Housing First programmes in Sweden - continues to face many barriers in the prevailing institutional order (Knutagård, 2015). Although the pilot was a success in making all ends meet, it has not yet affected the overall structure of the social housing programme or local governance.

Local initiatives that embrace a more radical view of social innovation do bring about some forms of institutional changes. However, even these differ with regard to conflict and/or collaboration. The Ilot Stephenson co-planning initiative was a local political process for the first ten years. The struggle against the dominant sociopolitical context then turned into the development of practices to better meet the particular housing needs of excluded groups. And yet, despite the interest expressed by professionals, students and activists, national urban planning policies have not been changed because of this initiative. The influence of such co-planning experimentations on the dominant national and urban revitalisation programmes seems to be limited in a national context where quantitative aims (build more) prevail over qualitative and innovative actions (participation and co-production). In the case of the Solidarity Clinic of Thessaloniki, relations with the state authorities have been adversarial because of the austerity-imposed policies in health care and the social struggle orientation of the initiative. Although similarly minded initiatives across the country have jointly formed a network of autonomous Solidarity Clinics to better channel their political demands, they have mostly engaged in public events 
and demonstrations. Relations with the national scale have been difficult, given the potential danger that solidarity health care provision may actually facilitate the further retrenchment of national health services. For this reason, they seem reluctant to collaborate with the state and to become institutionalised for fear of losing their autonomy and resistance dimension.

\section{CONCLUSIONS}

In this chapter we have analysed the socially innovative character of four local welfare initiatives in health and social services, that is, collective practices for developing new solutions or sustaining the welfare of individuals, groups and communities at the local level. The initiatives addressed were similar in terms of being grassroots endeavours that were developed as solutions to local social problems. All of them included local co-operation and, to some extent, integration among local and national welfare actors and institutions. Therefore, they represent new local combinations of actors in the welfare providers' 'diamond' (Leibetseder et al., in this volume). However, the four initiatives differed in terms of how they articulated social innovation, who the central actors involved were and what the level of institutionalisation was (see Table 13.1).

In a time of austerity, social innovations have become a focus of interest for local, national and EU social policies. Although local initiatives often represent citizens' solutions to failing or lacking public services and may be inspired by the goal to challenge the institutional order, regulatory and funding measures have been taken at national and EU levels to support social innovations as cost-effective methods of organising public services without altering the existing social order. Local initiatives are often grassroots solutions that may or may not develop into social innovations that last over time and can be transferred to other contexts. Social innovations have the potential to serve not only as a solution to local problems but also as a medium for social change; however, not all social innovations incorporate both of these aspects.

One central argument made in this chapter is that social innovations have a Janus face (Swyngedouw, 2005), which was illustrated in the analysis of the case studies. In assessing the value orientation of social innovations, as suggested by Vicari Haddock and Tornaghi (2013), the drive to act in the mainstream version of social innovation is to find a local remedy for the ills of failing social services and to mobilise local resources to find solutions that do not challenge the established power relations or the social order itself. By contrast, the value orientation inherent in the more radical 


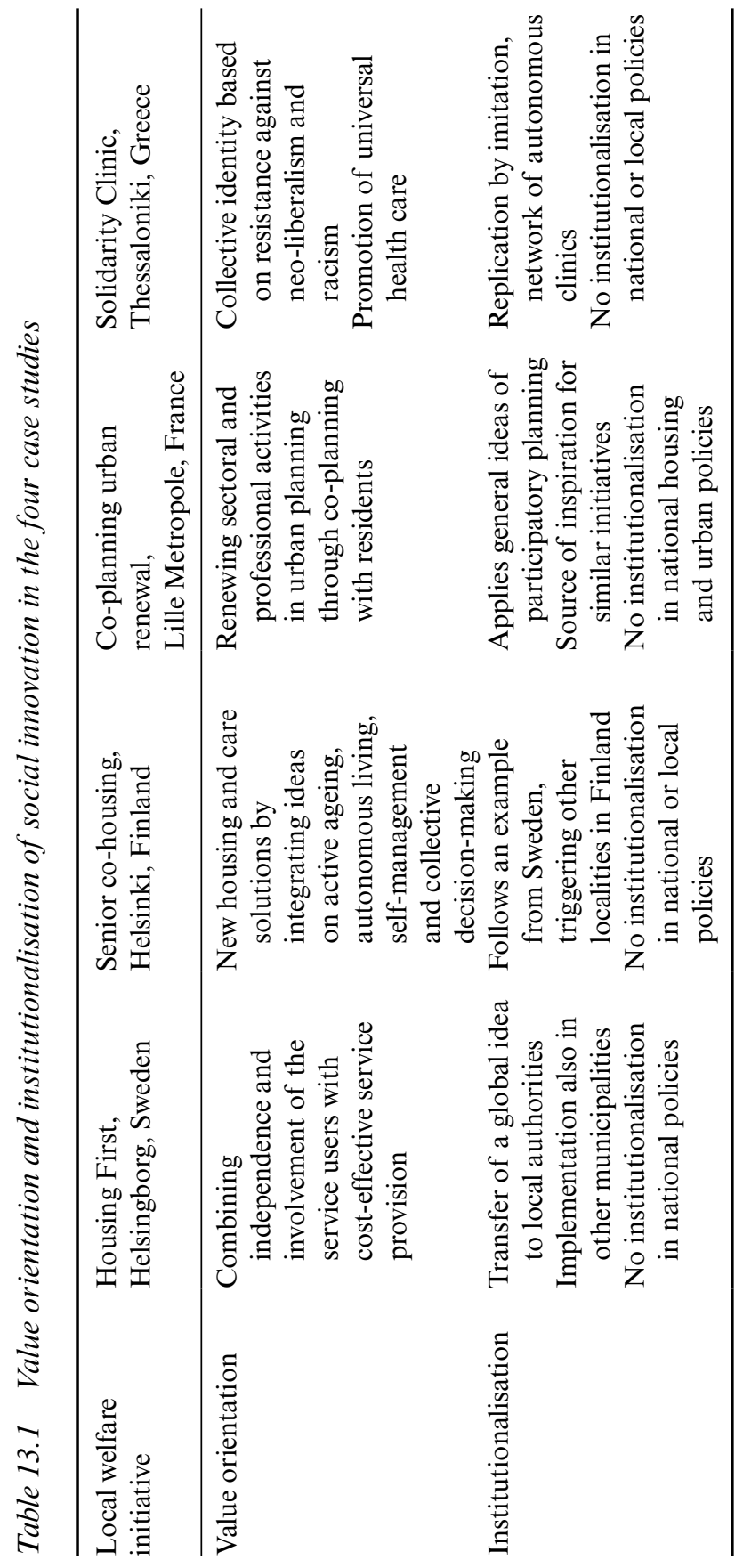


socially innovative initiatives encompasses a quest for social change by reorganising power relations and strengthening the participatory role of citizens as co-planners in welfare practices. Therefore, social innovations can be distinguished on the basis of who the key actors are and what the role (and power) of citizens is in relation to institutional actors and the dominant social order.

A key question concerning the opportunity to transform local initiatives into social innovations is their degree of institutionalisation. Some initiatives, such as the Solidarity Clinic in Greece and the co-planning initiative in Lille, France, stem from local social problems, whereas others, such as the Housing First initiative, are inspired by a global policy concept and applied in a local context. The co-housing initiative in Helsinki represents a local solution to the quest for finding alternative housing options for older people based on a co-housing model adopted from a neighbouring country. All of these initiatives have stood the test of time and have not died out, but their level and form of institutionalisation vary.

Housing First in Sweden and co-housing in Finland have involved a close collaboration among local citizens, communities and institutional actors, and they seem to have the potential to be applied beyond a local context and to be further developed in collaboration with different actors. The likely reason for their sustainability is the co-operation among different actors and the fact that, to some extent, they complement formal welfare services without seriously questioning the existing order. In contrast, the co-planning urban project in Lille, France and the Solidarity Clinic in Greece seek to question the dominant sociopolitical order and to develop local solutions that challenge its legitimacy. They too have endured, but to date none of these initiatives has managed to truly alter governance arrangements or national welfare policies. However, they have managed to introduce the ideas of the participation of citizens and the co-production of services at the local level and to offer solutions to local problems. In this regard, they have managed to create new local combinations among public actors, third sector organisations and community networks (Evers and Ewert, 2015) in organising welfare services and developing new solutions to local social problems. The Solidarity Clinic, in particular, stands out for its commitment to work outside established formal structures.

To some extent, all four initiatives addressed in this chapter share the goal of spreading social innovation beyond the local level and establishing new practices that could engender more permanent social change. However, a closer examination gives reason to argue that the promise of local initiatives to develop into social innovations that challenge and reorganise the existing power relations among institutional actors, local communities and 
citizens (Moulaert et al., 2005) is, to date, unfulfilled. Whether they will do so in the future or whether they will further strengthen the complementary role of local initiatives as part of mainstream welfare solutions remains to be seen.

\section{REFERENCES}

Adam, S. and C. Papatheodorou (2014), 'Social medical centers of solidarity in turbulent times', unpublished paper presented at the COST Action IS1102 Workshop, University of Tampere, Tampere, 2-6 June.

Andreotti, A., E. Mingione and E. Polizzi (2012), 'Local welfare systems: a challenge for social cohesion', Urban Studies, 49 (9), 1925-40.

BEPA - Bureau of European Policy Advisers (2010), 'Empowering people, driving change: social innovation in the European Union', accessed 28 June 2016 at http://ec.europa.eu/DocsRoom/documents/13402/attachments/1/translations/en/ renditions/native.

Bergmark, A., Å. Bergmark and T. Lundström (2011), Evidensbaserat Socialt Arbete: Teori, Kritik, Praktik, Stockholm: Natur och Kultur.

Brandsen, T., A. Evers, S. Cattacin and A. Zimmer (2016), 'Social innovation: a systematic and critical interpretation', in T. Brandsen, A. Evers, S. Cattacin and A. Zimmer (eds), Social Innovations in the Urban Context, London: Springer Open, pp. 3-21.

Castells, M. (1983), The City and the Grassroots. A Cross-cultural Theory of Urban Social Movements, Berkeley: University of California Press.

Chambon, J.-L., A. David and J.-M. Devevey (eds) (1982), Les Innovations Sociales, Paris: Presses Universitaires de France.

Dahlström, M. and S. Minkkinen (2009), Loppukiri. Vaihtoehtoista Asumista Seniori-iässä, Helsinki: WSOY.

European Commission (2013), Guide to Social Innovation, accessed 28 June 2016 at http://s3platform.jrc.ec.europa.eu/documents/20182/84453/Guide_to_Social_ Innovation.pdf.

Evers, A. (2015), 'Analyser en contexte la dimension normative de l'innovation sociale', interview conducted by Laurent Fraisse, Sociologies Pratiques, 31 (2), $15-21$.

Evers, A. and B. Ewert (2015), 'Social innovation for social cohesion', in A. Nicholls, J. Simon and M. Gabriel (eds), New Frontiers in Social Innovation Research, New York: Palgrave Macmillan, pp. 107-28.

Fraisse, L. (2013), 'The social and solidarity-based economy as a new field of public action: a policy and method for promoting social innovation', in F. Moulaert, D. MacCallum, A. Mehmood and A. Hamdouch (eds), The International Handbook on Social Innovation. Collective Action, Social Learning and Transdisciplinary Research, Cheltenham, UK and Northampton, MA, USA: Edward Elgar Publishing, pp. 361-71.

Fraisse, L. (2016), 'Lille Metropolis: co-production of housing in a major urban renewal district', in T. Brandsen, S. Cattacin, A. Evers and A. Zimmer (eds), Social Innovations in the Urban Context, London: Springer Open, pp. 205-13.

Gallouj, F. and F. Djellah (2010), The Handbook of Innovation and Services. A 
Multi-disciplinary Perspective, Cheltenham, UK and Northampton, MA, USA: Edward Elgar Publishing.

Gerometta, J., H. Häussermann and G. Longo (2005), 'Social innovation and civil society in urban governance: strategies for an inclusive city', Urban Studies, $\mathbf{4 2}$ (11), 2007-21.

Grimm, R., C. Fox, S. Baines and K. Albertson (2013), 'Social innovation, an answer to contemporary societal challenges? Locating the concept in theory and practice', Innovation: The European Journal of Social Science Research, 26 (4), 436-55.

Häikiö, L. (2007), 'Expertise, representation and the common good: grounds for legitimacy in the urban governance network', Urban Studies, 44 (11), 2147-62.

Häikiö, L. (2010), 'The diversity of citizenship and democracy in local public management reform', Public Management Review, 12 (3), 363-84.

Ifanti, A., A. Argyriou, F. Kalofonou and H. Kalofonos (2013), 'Financial crisis and austerity measures in Greece: their impact on health promotion policies and public health care', Health Policy, 113 (1-2), 8-12.

Jessop, B., F. Moulaert, L. Hulgård and A. Hamdouch (2013), 'Social innovation research: a new stage in innovation analysis?', in F. Moulaert, D. MacCallum, A. Mehmood and A. Hamdouch (eds), The International Handbook on Social Innovation. Collective Action, Social Learning and Transdisciplinary Research, Cheltenham, UK and Northampton, MA, USA: Edward Elgar Publishing, pp. 110-30.

Jolanki, O. (2014), 'Senior cohousing community as a way to organize help and support for older people', unpublished paper presented at the COST Action IS1102 Workshop, University of Tampere, Tampere, 2-6 June.

Jolanki, O. and A. Vilkko (2015), "The meaning of a "sense of community" in a Finnish senior cohousing community', Journal of Housing for the Elderly. Special Issue: Nordic Housing Research, 29 (1-2), 111-25.

Kentikelenis, A., M. Karanikolos, A. Reeves, M. McKee and D. Stuckler (2014), 'Greece's health crisis: from austerity to denialism', The Lancet, 383 (9918), 748-53.

Klein, J.-L., J.-L. Laville and F. Moulaert (2014), L'innovation Sociale, Toulouse: Erès.

Knutagård, M. (2014), 'The moral geography of homelessness', unpublished paper presented at the COST Action IS1102 Workshop, University of Tampere, Tampere, 2-6 June.

Knutagård, M. (2015), 'Bostad först som strategi eller strategisk strimma', Alkohol and Narkotika, no. 4, 12-15.

Knutagård, M. and A. Kristiansen (2013), 'Not by the book: the emergence and translation of Housing First in Sweden', European Journal of Homelessness, 7 (1), 93-115.

León, M., E. Pavolini and A.M. Guillén (2015), 'Welfare rescaling in Italy and Spain: political strategies to deal with harsh austerity', European Journal of Social Security, 17 (2), 182-201.

Lévesque, B. (2007), 'L'innovation dans le développement économique et le développement social', in J.-L. Klein and D. Harrisson (eds), L'innovation Sociale. Emergence et Effets sur la Transformation de la Société, Quebec: Presses de l’Université du Québec, pp. 43-68.

Manzini, E. (2014), 'Making things happen. Social innovation and design', Design Issues, 30 (1), 57-66. 
Martinelli, F. (2010), 'Historical roots of social change: philosophies and movements', in F. Moulaert, E. Swyngedouw, F. Martinelli and S. Gonzalez (eds), Can Neighbourhoods Save the City? Community Development and Social Innovation, London: Routledge, pp. 17-48.

Montgomery, T. (2016), 'Are social innovation paradigms incommensurable?', Voluntas: International Journal of Voluntary and Nonprofit Organizations, 27 (4), 1979-2000.

Moulaert, F., D. MacCallum, A. Mehmood and A. Hamdouch (eds) (2013), The International Handbook on Social Innovation: Collective Action, Social Learning and Transdisciplinary Research, Cheltenham, UK and Northampton, MA, USA: Edward Elgar Publishing.

Moulaert, F., F. Martinelli, S. González and E. Swyngedouw (2007), 'Introduction: social innovation and governance in European cities. Urban development between path dependency and radical innovation', European Urban and Regional Studies, 14 (3), 195-209.

Moulaert, F., F. Martinelli, E. Swyngedouw and S. González (2005), 'Towards alternative model(s) of local innovation', Urban Studies, 42 (11), 1969-90.

Moulaert F., E. Swyngedouw, F. Martinelli and S. Gonzalez (eds) (2010), Can Neighbourhoods Save the City? Community Development and Social Innovation, London: Routledge.

Mulgan, G. (2012), 'Social innovation theories: can theory catch up with practices?', in F. Hans-Werner, J. Hochgerner and J. Howaldt (eds), Challenge Social Innovation. Potentials for Business, Entrepreneurship, Welfare and Civil Society, Berlin and Heidelberg: Springer, pp. 19-43.

Nicholls, A., J. Simon and M. Gabriel (eds) (2015), New Frontiers in Social Innovation Research, New York: Palgrave Macmillan.

Rønning, R. and M. Knutagård (2015), Innovation in Social Welfare and Human Services, Abingdon, UK and New York, USA: Routledge.

Sanders, E.B.N. and P.J. Stappers (2008), 'Co-creation and the new landscapes of design', CoDesign, 4 (1), 5-18.

Swyngedouw, E. (2005), 'Governance, innovation and the citizen: the Janus face of governance-beyond-the-state', Urban Studies, 42 (11), 1991-2006.

Touraine, A. (1981), The Voice and the Eye: An Analysis of Social Movements, Cambridge: Cambridge University Press.

Tsemberis, S. (2010), Housing First: the Pathways Model to End Homelessness for People with Mental Illness and Addiction, Center City: Hazelden.

Vicari Haddock, S. and C. Tornaghi (2013), 'A transversal reading of social innovation in European cities', in F. Moulaert, D. MacCallum, A. Mehmood and A. Hamdouch (eds), The International Handbook on Social Innovation. Collective Action, Social Learning and Transdisciplinary Research, Cheltenham, UK and Northampton, MA, USA: Edward Elgar Publishing, pp. 264-73. 